патофизиологии, эпидемиологии, диагностики и интенсивной терапии: мат. межрегион. науч.-практ. конф. Кемерово, 2006. 107-117.

16. Скачкова Е.И., Гашаев А.В., Новожилов А.В. Инфекционная безопасность в медицинском учреждении. М., 2005. 70 с.

17. СП 3.1.2485-09 «Профилактика внутрибольничных инфекций в стационарах (отделениях) хирургического профиля лечебных организаций». М., 2009.

18. СанПиН 2.1.3.2524-09 «Санитарно-гигиенические требования к стоматологическим медицинским организациям». М., 2009.

19. СанПиН 2.1.3.2630-10 «Санитарно-эпидемиологические требования к организациям, осуществляющим медицинскую деятельность». М., 2010.

20. Царик Г.Н., Рычагов И.П., Шпилянский Э.М., Те И.А. Проблемы и перспективы разработки стандартов медицинских технологий регионального уровня // Сибирский консилиум. 2007. (5). 7075.

21. Царик Г.Н., Шпилянский Э.М., Рычагов И.П. Научное обоснование инновационных технологий организации и управления обеспечением качества медицинской помощи населению // Вопр. экспертизы качества мед. помощи. 2007. (1). 27-37.

22. Шикина И.Б., Кошель В.И., Восканян Ю.Э. и др. Пути обеспечения безопасности пациентов в многопрофильном стационаре: метод. рекомендации. Ставрополь, 2006. 27 с.

\title{
Garashova M.A. \\ Evaluation of the Endometrial Pathology in Women with Postmenopausal Bleeding
} Azerbaijan Medical University (Azerbaijan, Baku)

doi 10.18411/gq-30-11-2019-07

idsp sciencerussia-30-11-2019-07

\section{Аннотация}

Обследованы 101 женщина с постменопаузальным кровотечением. Средний возраст пациенток составил 59,7 $\pm 0,6$ (50-83) года. Средняя продолжительность менопаузы составила 9,4 \pm 0,8 (1-27) года. По данным ТВУ, у пациентов с раком эндометрия было определено статистически значимое увеличение размеров матки и размеров обоих яичников ( $<0,05)$, включая толщину эндометрия, которая варьировала в широких пределах (5- 100 мм). Было установлено, что из 101 пациентки с ПК у 48 (47,5\%) пациенток был выявлен рак эндометрия, у 30 (29,7\%) - диффузная гиперплазия эндометрия, у 13 (12,9\%) - атипическая гиперплазия и у 10 (9,9\%) - полип эндометрия. Результаты исследования подтвердили, что методом выбора для первичной оценки толщины эндометрия у женщин с наличием кровотечений в постменопаузальном периоде является ТВУ. Пайпель-биопсия имеет преимущества перед традиционными D \& C в диагностике патологии эндометрия

Ключевые слова: постменопаузальное кровотечение, патология эндометрия, Пайпель-биопсия.

In recent years, the number of women in the postmenopausal period has been growing steadily, which increases the need for specialized medical care for this category of women to improve their quality of life [1]. In women in the postmenopausal period, various gynecological diseases are often accompanied by vaginal spotting and bleeding. [2,3]. Postmenopausal vaginal bleeding (PB) is a bleeding that occurred spontaneously at least one year after the onset of menopause, and their incidence in early postmenopausal women is $10 \%$ [4]. The causes of PB are most often the increased thickening of the endometrium of varying severity against a background of benign and malignant transformation. According to scientific studies, the frequency of PB in patients with endometrial carcinoma is 10-15\%, with diffuse and focal endometrial hyperplasia is about $40 \%$ [5].

Diagnostics of endometrial hyperplasia and endometrial cancer is based on clinical symptoms, ultrasound data, results of hysteroscopy, morphological examination of endometrial sample, as well as the results of MRI. The main ultrasound indicators of 
endometrial pathology in postmenopausal women are: thickening of the endometrium more than $5 \mathrm{~mm}$ on the background of a long postmenopausal period; the presence of hypo-and anechogenic structures of various sizes in the uterine cavity even in normal indicators of the endometrial thickness; the presence of intrauterine hyperechogenic lesions with clear contours of more than $3 \mathrm{~mm}[6,7]$.

The diagnostic accuracy of ultrasound in the diagnosis of endometrial hyperplasia in the late reproductive and perimenopausal periods is $60 \%$. It should be noted that in $40 \%$ of patients with signs of complex endometrial hyperplasia by ultrasound, the diagnosis does not confirm the findings of a histological examination [8].

The presence of bloody vaginal discharge in postmenopausal women is the basis for the use of transvaginal ultrasonography to exclude the endometrial cancer. An indicator of endometrial thickness greater than $5 \mathrm{~mm}$ is one of the criteria for diagnosing of endometrial cancer and the specificity of this indicator is $61 \%$ [3,7].

At the same time, the degree of thickening of the endometrium in various diseases of the genitals in postmenopausal women is still the subject of debate. It should be noted that potential risk factors, such as age, duration of menopause, parity, body mass index, the presence of concomitant diseases (diabetes, hypertension, coronary heart disease), menopausal replacement therapy, and ovarian pathology can affect endometrial histopathology. Sometimes these factors cause an asymptomatic increase in the thickness of the endometrium over $>5 \mathrm{~mm}[9,10]$.

A traditional method for studying endometrial pathology is $\mathrm{D \& C}$ (dilatation and curettage). Currently, with the aim of obtaining an endometrial sample for primary histological examination, various devices are used. These devices are most often made of plastic and are characterized by elasticity and small diameter. The use of these devices allows the procedure to be carried out with a minimum expenditure of time and the absence of discomfort in patients. The most common method is Pipelle-biopsy $[9,11]$. Hysteroscopy with dilation and curettage is warranted method of evaluation of endometrial pathology in women with persistent or recurrent bleeding, in case if blind sampling does not reveal endometrial hyperplasia or malignancy.

The aim of the study was evaluation of the endometrial pathology in women with the postmenopausal bleeding.

Material and methods. 101 patients with PB were examined. The average age of patients was $59.7 \pm 0.6(50-83)$ years. The average duration of menopause was $9.4 \pm 0.8$ (127 ) years. All patients underwent a clinical examination. Anamnestic data were collected, age, parity, time and duration of menopause were determined, past and chronic diseases, hormonal drugs, a surgical history of performed gynecological and extragenital surgical interventions were identified, and an obstetric history was collected. For all the patients body mass index (BMI) was calculated. All patients underwent transvaginal ultrasound. If necessary, an MRI scan was performed. A histopathological examination was performed for all patients with a thickening of the endometrium according to the TU data using Pipelle-biopsy or the standard method of dilatation and curettage of the uterine cavity.

Results. A prospective comparative study of 101 patients with various endometrial pathology accompanied by vaginal bleeding was carried out; the average age was $59.7 \pm$ $0.6(50-83)$ years, body mass index (BMI) was $32.7 \pm 10(23.2-58.0) \mathrm{kg} / \mathrm{m} 2$, the frequency of infertility was $14.9 \%(n=7)$.

The results of an echographic study showed that the thickness of the endometrium with endometrial hyperplasia ranged from $14.1 \pm 1.6 \mathrm{~mm}$ in patients with atypical endometrial hyperplasia to $21.3 \pm 4.8 \mathrm{~mm}$ for diffuse endometrial hyperplasia. The thickness of the endometrium in endometrial cancer averaged $24.9 \pm 2.7 \mathrm{~mm}$.

According to TVU data, in patients with endometrial cancer in postmenopausal period a statistically significant increase in uterine size was determined, including the thickness of the endometrium, which varied in a wide range $(5-100 \mathrm{~mm})$. It was also found a statistically 
significant increase in the size of both ovaries compared with the control group $(\mathrm{p}<0.05)$. Table 1).

Table 1

Echographic parameters of female genitalia in patients with $P B(M \pm m)$

\begin{tabular}{|c|c|c|c|c|c|c|}
\hline $\begin{array}{l}\text { Echograp } \\
\text { hic } \\
\text { parameter } \\
\text { s }\end{array}$ & $\begin{array}{l}\text { Endom } \\
\text { etrial } \\
\text { cancer }\end{array}$ & $\begin{array}{c}\text { Complex } \\
\text { endometrial } \\
\text { hyperplasia } \\
\text { without atypia }\end{array}$ & $\begin{array}{c}\text { Complex } \\
\text { endometrial } \\
\text { hyperplasia with } \\
\text { atypia }\end{array}$ & $\begin{array}{l}\text { Endometrial } \\
\text { polyp }\end{array}$ & $\begin{array}{l}\text { Control } \\
\text { group }\end{array}$ & $\begin{array}{l}\text { Significance of } \\
\text { the differences P }\end{array}$ \\
\hline \multicolumn{7}{|l|}{ Uterus } \\
\hline $\begin{array}{c}\text { length, } M \\
M \\
M \pm m\end{array}$ & $\begin{array}{c}63,4 \pm \\
3,3 \\
(34- \\
126)\end{array}$ & $\begin{array}{c}60,4 \pm 4,4 \\
0-150)\end{array}$ & $\begin{array}{c}57,3 \pm 3,7 \\
-90,4)\end{array}$ & $\begin{array}{l}58,2 \pm 3,7 \\
\quad(35-77)\end{array}$ & $\begin{array}{c}44,44 \pm \\
0,9 \\
(25-58)\end{array}$ & $\begin{array}{c}\mathrm{P} 1>0,05 ; \mathrm{P} 2<0,05 ; \mathrm{P} \\
3<0,05 ; \mathrm{P} 4<0,05\end{array}$ \\
\hline $\begin{array}{l}\text { width, } \mathrm{MM} \\
\mathrm{M} \pm \mathrm{m}\end{array}$ & $\begin{array}{c}52,1 \pm \\
2,4 \\
(20- \\
78) \\
\end{array}$ & $\begin{array}{l}49,2 \pm 3,5 \\
21-109)\end{array}$ & $\begin{array}{c}48,4 \pm 3,5 \\
3-81)\end{array}$ & $\begin{array}{c}47,7 \pm 4,1 \\
4-70)\end{array}$ & $\begin{array}{c}40,66 \pm \\
0,08 \\
(35-45)\end{array}$ & $\begin{array}{c}\mathrm{P} 1>0,05 \\
\mathrm{P} 2<0,05 ; \mathrm{P} 34<0,05 \\
\mathrm{P} 4>0,05\end{array}$ \\
\hline $\begin{array}{l}\text { Antero- } \\
\text { posterior } \\
\text { diameter, } \\
\text { MM } \mathrm{M} \pm \\
\mathrm{m}\end{array}$ & $\begin{array}{c}54,2 \pm \\
2,3 \\
(33- \\
80)\end{array}$ & $\begin{array}{c}52,8 \pm 3,5 \\
3-105)\end{array}$ & $\begin{array}{c}45,6 \pm 4,4 \\
2-87)\end{array}$ & $\begin{aligned} 59,8 \pm 4,0 \\
(38-77)\end{aligned}$ & $\begin{array}{c}27,76 \pm \\
0,025 \\
(18-32)\end{array}$ & $\mathrm{P} 1-4<0,05$ \\
\hline 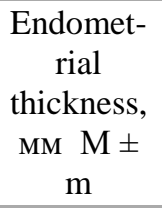 & $\begin{array}{c}24,9 \pm \\
2,7 \\
(5- \\
100)\end{array}$ & $\begin{array}{r}21,3 \pm 4,8 \\
, 8-176)\end{array}$ & $\begin{array}{r}14,1 \pm 1,6 \\
6-28)\end{array}$ & $\begin{array}{r}16,5 \pm 1,7 \\
0-33)\end{array}$ & $\begin{array}{c}2,20 \pm \\
0,05 \\
(0,6-1,4)\end{array}$ & $\mathrm{P} 1-4<0,05$ \\
\hline \multicolumn{7}{|l|}{$\begin{array}{l}\text { Right } \\
\text { ovary: }\end{array}$} \\
\hline $\begin{array}{c}\text { length, } \mathrm{M} \\
\mathrm{M} \\
\mathrm{M} \pm \mathrm{m}\end{array}$ & $\begin{array}{c}26,8 \pm \\
2,0 \\
(15- \\
38)\end{array}$ & $\begin{array}{r}38,4 \pm 8,2 \\
3-97)\end{array}$ & $\begin{array}{r}43,3 \pm 6,6 \\
24-93)\end{array}$ & $\begin{array}{c}25,8 \pm 5,3 \\
6-41)\end{array}$ & $\begin{array}{c}18,82 \pm \\
0,09 \\
(10-20)\end{array}$ & $\begin{array}{c}\mathrm{P} 1<0,05 \\
\mathrm{P} 2<0,05 ; \mathrm{P} 3<0,05 \\
\mathrm{P} 4>0,05\end{array}$ \\
\hline $\begin{array}{l}\text { width, } \mathrm{MM} \\
\mathrm{M} \pm \mathrm{m}\end{array}$ & $\begin{array}{c}18,3 \pm \\
1,4 \\
(11- \\
27)\end{array}$ & $\begin{array}{r}35,1 \pm 7,6 \\
12-83)\end{array}$ & $\begin{array}{r}32,3 \pm 2,2 \\
5-68)\end{array}$ & $\begin{array}{c}17,0 \pm 2,9 \\
11-24)\end{array}$ & $\begin{array}{c}11,10 \pm \\
0,04 \\
(8-14)\end{array}$ & $\begin{array}{c}\mathrm{P} 1<0,05 \\
\mathrm{P} 2<0,05 ; \mathrm{P} 3<0,05 \\
\mathrm{P} 4>0,05\end{array}$ \\
\hline $\begin{array}{c}\text { Antero- } \\
\text { posterior } \\
\text { diameter, } \\
\text { MM } \mathrm{M} \pm \\
\mathrm{m}\end{array}$ & $\begin{array}{c}23,4 \pm \\
0,8 \\
(12- \\
26)\end{array}$ & $\begin{array}{r}24,5 \pm 2,1 \\
11-24)\end{array}$ & $\begin{array}{r}26,4 \pm 2,4 \\
13-56)\end{array}$ & $\begin{array}{r}19,3 \pm 2,4 \\
14-25)\end{array}$ & $\begin{array}{c}15,90 \pm \\
0,07 \\
(12-20)\end{array}$ & $\begin{array}{c}\mathrm{P} 1<0,05 ; \mathrm{P} 2<0,05 ; \mathrm{P} \\
3<0,05 ; \quad \mathrm{P} 4>0,05\end{array}$ \\
\hline \multicolumn{7}{|l|}{$\begin{array}{c}\text { Left } \\
\text { ovary: }\end{array}$} \\
\hline $\begin{array}{c}\text { length, } \mathrm{M} \\
\mathrm{M} \\
\mathrm{M} \pm \mathrm{m}\end{array}$ & $\begin{array}{c}28,3 \pm \\
1,9 \\
(16- \\
36)\end{array}$ & $\begin{array}{r}36,1 \pm 7,7 \\
2-85)\end{array}$ & $\begin{array}{r}33,2 \pm 5,6 \\
11-72)\end{array}$ & $\begin{array}{l}26,1 \pm 4,9 \\
\quad(15-38)\end{array}$ & $\begin{array}{c}19,34 \pm \\
0,07 \\
(10-25)\end{array}$ & $\begin{array}{c}\mathrm{P} 1<0,05 \\
\mathrm{P} 2<0,05 ; \mathrm{P} 3<0,05 \\
\mathrm{P} 4>0,05\end{array}$ \\
\hline $\begin{array}{l}\text { width, } \mathrm{Mm} \\
\mathrm{M} \pm \mathrm{m}\end{array}$ & $\begin{array}{c}17,9 \pm \\
1,2 \\
(10- \\
25)\end{array}$ & $\begin{array}{r}32,3 \pm 5,8 \\
10-76)\end{array}$ & $\begin{array}{c}31,8 \pm 2,4 \\
2-58)\end{array}$ & $\begin{array}{c}16,9 \pm 3,4 \\
12-24)\end{array}$ & $\begin{array}{c}10,74 \pm \\
0,05 \\
(8-14)\end{array}$ & $\begin{array}{c}\mathrm{P} 1<0,05 ; \mathrm{P} 2<0,05 ; \mathrm{P} \\
3<0,05 ; \quad \mathrm{P} 4>0,05\end{array}$ \\
\hline $\begin{array}{c}\text { Antero- } \\
\text { posterior } \\
\text { diameter, } \\
\text { MM } \mathrm{M} \pm \\
\mathrm{m}\end{array}$ & $\begin{array}{c}20,2 \pm \\
0,3 \\
(11- \\
24)\end{array}$ & $\begin{array}{c}25,1 \pm 3,0 \\
2-26)\end{array}$ & $\begin{array}{c}26,4 \pm 1,9 \\
1-29)\end{array}$ & $\begin{array}{r}18,1 \pm 3,1 \\
3-24)\end{array}$ & $\begin{array}{c}14,59 \pm \\
0,08 \\
(12-18)\end{array}$ & $\begin{array}{c}\mathrm{P} 1<0,05 ; \mathrm{P} 2<0,05 ; \mathrm{P} \\
3<0,05 ; \quad \mathrm{P} 4>0,05\end{array}$ \\
\hline
\end{tabular}


$26(25.7 \%)$ patients included in this study underwent endometrial biopsy using the standard D\&C method, $72(71.3 \%)$ patients underwent a Pipelle-biopsy. In 3 (3.0\%) patients, preoperative diagnosis of endometrial sample was not performed, due to the technical impossibility of the procedure: 1 patient had cervical stenosis, in 2 patients the uterine cavity was completely filled with lesion.

D\&C was performed for diagnostic and treatment purposes in patients with recurrent uterine bleeding. The obtained endometrial samples were sent for histopathological examination, as a result of which out of 26 patients, endometrial carcinoma was revealed in 6 $(23 \%)$, in $5(19.2 \%)$ atypical hyperplasia, in $12(46.2 \%)$ diffuse hyperplasia and in $3(11.5 \%)$ patients endometrial polyp was determined. All patients in this group underwent surgery followed by histological examination of the material. According to the results of a postoperative histological examination, the diagnosis of endometrial carcinoma was confirmed in all 6 patients, as well as in 2 patients with diffuse hyperplasia and 1 patient with endometrial polyp. 72 patients with PB underwent a Pipelle-biopsy. Of these, 34 (47.2\%) patients were diagnosed with endometrial carcinoma, 10 (13.9\%) atypical hyperplasia, 22 $(30.5 \%)$ patients with diffuse complex hyperplasia, and $6(8.3 \%)$ with endometrial polyps. After evaluating the results of a postoperative histological examination, it was found that of 10 patients with atypical hyperplasia, 2 had endometrial cancer, and of 22 patients with diffuse hyperplasia, 2 had an endometrial polyp.

Thus, it was found that out of 101 patients with PB , 48 (47.5\%) patients had endometrial cancer, $30(29.7 \%)$ patients had diffuse endometrial hyperplasia, 13 (12.9\%)atypical hyperplasia and in $10(9.9 \%)$ patients with endometrial polyp.

The results obtained showed that Pipelle-biopsy has advantages over the traditional $\mathrm{D} \& \mathrm{C}$ method and can be used to diagnose endometrial pathology. The disadvantage of D\&C is the impossibility in most cases of a complete evacuation of the uterine cavity, which leads to diagnostic errors, as well as the painfulness of the procedure, requiring anesthesia. In this study, the detection rate of endometrial cancer with this method was $66.7 \%$. ( table 2).

Table 2.

The diagnostic accuracy of the Pipelle-biopsy for various pathologies of the endometrium in

\begin{tabular}{|c|c|c|c|c|}
\hline \multicolumn{5}{|c|}{ the postmenopausal period } \\
\hline Stat.indicators (\%) & $\begin{array}{l}\text { Endometrial } \\
\text { cancer }\end{array}$ & $\begin{array}{c}\text { Complex endometrial } \\
\text { hyperplasia without } \\
\text { atypia }\end{array}$ & $\begin{array}{l}\text { Complex endometrial } \\
\text { hyperplasia with atypia }\end{array}$ & $\begin{array}{l}\text { Endometrial } \\
\text { polyp }\end{array}$ \\
\hline $\begin{array}{l}\text { Sensitivity-real (+) } \\
\text { results (Sn) }\end{array}$ & $95,0 \pm 3,4$ & 100,0 & 100,0 & $66,7 \pm 13,6$ \\
\hline $\begin{array}{l}\text { Specitivity-real(-) } \\
\text { rezults(Sp) }\end{array}$ & $95,7 \pm 3,0$ & $93,5 \pm 3,1$ & $97,4 \pm 1,8$ & $94,6 \pm 2,6$ \\
\hline $\begin{array}{l}\text { Predictive utility }(+) \\
\text { rezalts (pPV) }\end{array}$ & $95,0 \pm 3,4$ & $85,7 \pm 6,6$ & $83,3 \pm 10,8$ & $66,7 \pm 13,6$ \\
\hline $\begin{array}{l}\text { Predictive utility (-) } \\
\text { rezalts (nPv) }\end{array}$ & $95,7 \pm 3,0$ & 100,0 & 100,0 & $94,6 \pm 2,6$ \\
\hline $\begin{array}{l}\text { General diagnostic } \\
\text { accuracy of the test }\end{array}$ & $95,3 \pm 2,3$ & $95,3 \pm 2,3$ & $97,7 \pm 1,6$ & $90,7 \pm 3,1$ \\
\hline $\begin{array}{l}\text { Likelihood ratio }(+) \text { of } \\
\text { the rezalts (LR+) }\end{array}$ & $\begin{array}{l}21,85 \\
\text { (dif.) }\end{array}$ & $\begin{array}{l}15,50 \\
\text { (dif.) }\end{array}$ & $\begin{array}{l}38,00 \\
\text { (dif.) }\end{array}$ & $\begin{array}{l}12,33 \\
\text { (dif.) }\end{array}$ \\
\hline $\begin{array}{l}\text { Likelihood ratio (-) } \\
\text { rezalts (LR-) }\end{array}$ & $\begin{array}{l}0,05 \\
\text { (dif.) }\end{array}$ & $\begin{array}{l}0,00 \\
\text { (dif.) }\end{array}$ & $\begin{array}{l}0,00 \\
\text { (dif.) }\end{array}$ & $\begin{array}{l}0,35 \\
\text { (indif.) }\end{array}$ \\
\hline
\end{tabular}

As can be seen from the table, the sensitivity of the Pipelle-biopsy method for the diagnosis of endometrial cancer was $95.0 \pm 3.4 \%$, and the specificity was $95.7 \pm 3.0 \%$. The frequency of unsatisfactory histology results depends on the improper sampling of the material or its insufficient amount for smear preparation and is $15 \%$ with D\&C, and $13 \%$ with Pipelle-biopsy. In postmenopausal women, these indicators are higher and make up $12 \%$ and 
$22 \%$, respectively, which is explained by the high incidence of cervical stenosis and endometrial atrophy in patients of the older age group [12,13].

Conclusion. The results of study confirmed that the method of choice for the initial assessment of the endometrial thickness in women with the presence of PB is TVU as a noninvasive and affordable diagnostic method. The diagnostic value of TVU in determining the degree of invasion of myometrium and preoperative staging of endometrial cancer is high. In case of unsatisfactory results of TVU, further instrumental diagnostic research methods are recommended.

$$
* * *
$$

1. Bradley L.D. Investigation of abnormal uterine bleeding in postmenopausal women // Hysteroscopy, 2009.

2. Bugaytsev, S.S., Tyueva, N.V., Shcherbina, A.B. On precancerous pathology, preinvasive and early endometrial cancer // Oncology, 2009, v.11, N 4, p.254

3. Breijer M.C., Timmermans A., van Doorn H.C. Diagnostic strategies for postmenopausal bleeding // Am.J.Obs.Gyn.Int., 2010, p. 850812. DOI:IO.1155/2010/050812.

4. Goldstein S.R. The role of transvaginal ultrasound or endometrial biopsy in the evaluation of the menopausal endometrium // Am.J.Obstet.Gynecol., 2010, vol.202, №3, p.10-11. https://doi.org/10.1016/j.ajog.2009.02.006.

5. Sheshukova N.A., Makarov I.O., Fomina M.N. Endometrial hyperplastic processes: etiopathogenesis, clinic, diagnosis, treatment // Obs.Gyn., 2011, N4, p.16-21.

6. Visser N.C., Breijer M.C., Herman M.C. Factors attributing to the failure of endometrial sampling in women with postmenopausal bleeding // Acta Obstet Gynecol Scand., 2013, vol.92, №10, p.1216-1222. DOI: IO.2147/IJWH.S172696

7. Hartman A, Wolfman W, Nayot D, Hartman M. Endometrial thickness in 1500 asymptomatic postmenopausal women not on hormone replacement therapy // Gynecol. Obstet. Invest., 2013, №75, p.191195. DOI: IO.1159/000347064.

8. Papadia A., Gerbaldo D., Fulcheri E. The risk of premalignant and malignant pathology in endometrial polyps: should every polyp be resected? // Minerva Ginec., 2007, vol.59, №2, p.117-124.

9. Sanam M., Mir Mohammad K.M. Comparison the diagnostic value of dilatation and curettage versus endometrial biopsy by pipelle - a clinical trial Asian Pacific Journal of Cancer Prevention, 2015, vol.16, p.4971-4975. // DOI: http//dx.doi.org/10.7314/APJCP.2015.16.12.4971

10. Sany O., Singh K., Jha S. Correlation between preoperative endometrial sampling and final endometrial cancer histology // Eur J Gynaecol Oncol, 2012, №33, p.142-144.

11. Siam S., Abd El-Hameed A.A. Thickened endometrium in asymptomatic postmenopausal women: Is biopsy mandatory? // Med. J. Cairo. Univ., 2011, №79, p.723-727.

12. Sweet M.G., Schmit Dalton T.A., Weiss P.M. Evaluation and management of abnormal uterine bleeding in premenopausal women // American Family Physician, 2012, №85, p.35-43.

13. van Hanegem N., Prins M.M., Bongers M.Y. The accuracy of endometrial sampling in women with postmenopausal bleeding: a systematic review and meta-analysis // Eur.J.Obstet.Gynecol.Reprod.Biol., 2016, №197, p.147-155. doi:io.1016/j.ejogrb.2015.12.008

\section{Melikova N.V. \\ Obesity as a risk factor for the development of cardiovascular diseases}

Azerbaijan Medical University (Azerbaijan, Baku)

doi 10.18411/gq-30-11-2019-08

idsp sciencerussia-30-11-2019-08

\section{Аннотация}

Статья посвящена изучению некоторых биохимических показателей сыворотки крови больных, страдающих от ожирения. Диагностика ожирения, последующий контроль за состоянием больного, оценка эффективности проводимой терапии требуют постоянных заборов крови для анализа. Результаты проведенных исследований еще раз доказали, что у больных, страдающих от ожирения остро нарушается углеводный и липидный обмен и развивается инсулинорезистентность. При ожирении в организме нарушается равновесие про-и антиокидантных систем, повышается активность ферментов антиоксидантных систем SOD, каталазы, GP, в то же время снижается 